\section{PEMBERDAYAAN IBU RUMAH \\ TANGGA YANG TERINFEKSI HIV/AIDS DI DESA JABON JOMBANG DENGAN MEMOTIVASI KEWIRAUSAHAN MANDIRI}

\section{Siti Mudrikatin}

Sekolah Tinggi Ilmu Kesehatan Husada Jombang

\author{
*Corresponding Author \\ Email : mudrisiti@gmail.com
}

Abstraksi
Kegiatan pengabdian pada masyarakat ini dilatar belakangi adanya permasalahan mitra berkaitan dengan fenomena HIV/AIDS di Kabupaten Jombang yang menempati posisi ranking 2 se Jawa Timur. Kegiatan ini dilaksanakan dengan cara memberi pelatihan sampai bisa membuat suatu produk sabun dari minyak zaitun, dengan inovasi baru akan memotivasi para ibu rumah tangga untuk berwirausaha mandiri di rumahnya sehingga home industri akan menjamur di Kabupaten Jombang. Tujuan dilakukan kegiatan pengabdian Ini diharapkan dapat meningkatkan kewirausahaan mandiri dengan motivasi dalam pembuatan sabun dari minyak zaitun. Hasil dalam kegiatan menunjukkan bertambahnya ilmu pengetahuan dan pemahaman kewirausahaan mandiri dalam membuat sabun dari minyak zaitun pada ibu rumah tangga yang terinfeksi HIV/AIDS di Kabupaten Jombang.

Kata Kunci : Pemberdayaan,Wirausaha Mandiri Pembuatan sabun dari minyak zaitun

\begin{abstract}
Community service activities are motivated by the presence of partner problems related to the phenomenon of HIV / AIDS in Jombang which ranks second in East Java. This activity is carried out by giving training to be able to make a soap product from olive oil, with new innovations will motivate housewives to be independent entrepreneurs in their homes so that home industries will mushroom in Jombang. The purpose of the community service activities is expected to increase independent entrepreneurship with motivation in making soap from olive oil. The results of the activity show the increasing knowledge and understanding of independent entrepreneurship in making soap from olive oil in housewives infected with HIV / AIDS in Jombang.
\end{abstract}

Keywords: Empowerment, Independent Entrepreneur, Manufacture of soap from olive oil 


\section{PENDAHULUAN}

Di era globalisasi ini, di tengahtengah pada kemajuan teknologi yang sangat cepat sudah seharusnya diimbangi dengan pertumbuhan dan peningkatan pada kualitas mutu Sumber Daya Manusia yang bukan lagi berangkat dari mindset bukan lagi mencari pekerjaan tetapi bagaimana SDM itu sendiri mampu dan dapat menciptakan lapangan pekerjaan sendiri (mandiri). Adapun yang tuntutan dalam menciptakan lapangan pekerjaan diantaranya yang sangat perlu diperhatikan adalah memiliki skill atau keterampilan di bidang usaha tertentu, pandai melihat kebutuhan pasar, dan dapat juga untuk mengetahui kemampuan ekonomi pada masyarakat sekitarnya. Saat ini maraknya wirausaha di berbagai daerah menjadi tuntutan utama bagi para SDM di Indonesia.

Tahun 2016 World Health Oraganization (WHO) mengumumkan 34 juta orang di dunia mengidap virus HIV penyebab AIDS dan sebagian besar dari mereka hidup dalam kemiskinan dan di negara berkembang. Data WHO terbaru juga menunjukkan peningkatan jumlah pengidap HIV yang mendapatkan pengobatan. Tahun 2013 tercatat 9,7 juta orang angka ini meningkat 300.000 orang lebih banyak dibandingkan 1 dekade sebelumnya (WHO 2016). Berdasarkan jenis kelamin kasus tertinggi HIV dan AIDS di Afrika adalah penderita dengan jenis kelamin perempuan hingga mencapai $81,7 \%$ terutama pada kelompok ibu rumah tangga dengan presentase paling tinggi dibandingkan dengan kelompok beresiko lainnya. Berdasarkan data Ditjen PP dan PL.Kemenkes RI tahun 2015, kasus HIV dan AIDS di Indonesia pada triwulan bulan Juli-September tercatat kasis HIV 7.335, sedangkan kasus AIDS 176 kasus. Estimasi dan proyeksi jumlah orang dengan HIV dan AIDS (ODHA) menurut populasi beresiko dimana jumlah ODHA dipopulasi ibu rumah tangga mengalami peningkatan dari 190.349 kasus pada tahun 2011 menjadi 279.276 kasus di tahun 2016 (Kemenkes RI 2014). Berdasarkan data di Provinsi Jawa Timur pada tahun 2014 ditemukan 
kasus HIV/Aids sebanyak 2.498 kasus, dengan perincian kasus HIV 2.069 orang dan AIDS 428 orang. Berdasarkan jenis pekerjaan ibu rumah tangga dengan HIV/AIDS dalam beberapa tahun terakhir ini mengalami peningkatan mencapai $18,5 \%$ menduduki peringkat pertama. Data Dinas Kesehatan Kabupaten Jombang tahun 2016 tercatat 1.020 orang terjangkit HIV dan AIDS. Mayoritas yang ditemukan adalah ibu rumah tangga.

Pemberdayaan pada masyarakat atau community empowering yang baik seyogyanya dapat mampu mengakomodir berbagai aspek yang berkembang dan dibutuhkan pada masyarakat. Masyarakat memerlukan peningkatan kesejahteraan, namun juga berharap agar pada pencapaian kesejahteraan tersebut tidak mengorbankan aspek- aspek lainnya, seperti budaya, keserasian lingkungan dan jati diri sebagai bagian dari sebuah komunitas. Salah satu desa di Kota Jombang yang dapat peneliti berdayakan melalui pembekalan skill sehingga mampu untuk bersaing dalam hal berwirausahaan yaitu di Kabupaten Jombang. Berikut Data situasi yang ada di Desa Jabon, Kecamatan Jombang Kabupaten Jombang :

Pekerjaan Ibu yang terinfeksi HIV/AIDS

Di Wilayah Jombang

\begin{tabular}{|l|l|l|}
\hline No & \multicolumn{1}{|c|}{ Keterangan } & \multicolumn{1}{c|}{ Jumlah } \\
\hline 1. & Ibu Rumah Tangga & 31 orang \\
\hline 2. & Wiraswasta & 14 orang \\
\hline
\end{tabular}

Sumber Data: Primer tahun 2018

Dari data diatas berimplikasi terhadap jumlah pengangguran yang besar terutama pada kaum perempuan di Desa Jabon yang mayoritas hanya menjadi ibu rumah tangga, selain itu SUB yang sangat sedikit hanya 16 industri rumah tangga selebihnya menjadi buruh di SUB tersebut mengingat tingginya jumlah penduduk yang tidak tamat $\mathrm{SD}$ atau sederajat. Selain itu masyarakat Pra Sejahtera di Desa Jabon.

Berikut beberapa bangunan pra sejahtera yang banyak ditemukan di desa Jabon Jombang. 


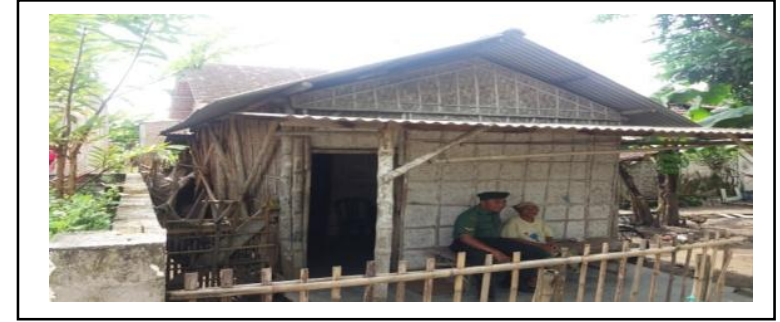

Gambar I : Rumah Masyarakat Pra Sejahtera Desa Jabon

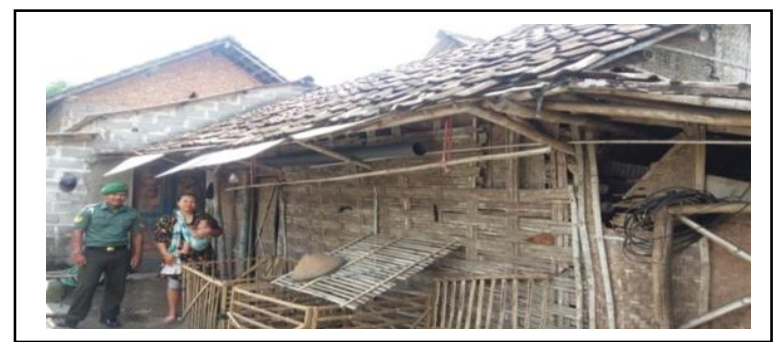

Gambar 2 : Rumah Masyarakat Pra Sejahtera Desa Jabon

Maka dengan gambar diatas, menunjukkan bahwa kemampuan masyarakat yang dapat dikembangkan tentunya banyak sekali seperti kemampuan untuk berusaha, kemampuan untuk mencari informasi, kemampuan untuk dalam mengelola kegiatan di desa, kemampuan dalam pertanian dan masih banyak lagi sesuai dengan kebutuhan atau permasalahan yang dihadapi oleh masyarakat. Apa yang perlu dikembangkan dari masyarakat sendiri, yaitu suatu potensi atau kemampuannya, dan sikap dalam hidupnya. Kemampuan masyarakat yang meliputi antara lain kemampuan untuk bertani, berternak, melakukan wirausaha, keterampilan membuat home industry mandiri; dan masih banyak lagi kemampuan dan keterampilan masyarakat yang dapat dikembangkan.

Dalam rangka mengembangkan kemampuan dan keterampilan masyarakat, dapat dilakukan dengan berbagai cara, contohnya mengadakan pelatihan atau mengikutkan masyarakat pada pelatihan-pelatihan pengembangan kemampuan dan keterampilan yang dibutuhkan. Dapat juga dengan mengajak masyarakat mengunjungi kegiatan di tempat lainnya dengan maksudnya supaya masyarakat dapat melihat sekaligus belajar, kegiatan ini sering disebut juga dengan istilah studi banding.

Berdasarkan analisis situasi diatas, maka beberapa temuan yang telah diidentifikasi sebagai permasalahan mitra antara lain adalah :

- Rendahnya angkatan kerja yang tidak tamat SD atau Sederajat

- Sebagian besar kaum wanita perempuan disana hanya sebagai Ibu rumah Tangga 
- Masih tingginya

masyarakat

Pra Sejahtera

- Rendahnya industri kecil rumahan

- Rendahnya kemauan para Ibu rumah tangga untuk memulai berwirausaha

- Ibu yang terinfeksi HIV/AIDS adalah ibu rumah tangga

Solusi dalam Program Pengabdian kepada Masyarakat atau Praktek Kemitraan Masyarakat (PKM) yang disusun ini dimaksudkan untuk mewujudkan pemberdayaan terhadap ibu-ibu rumah tangga yang terinfeksi HIV/AIDS yang ada di Desa Jabon untuk memiliki mindset berwirausaha sehingga mampu dalam menghasilkan suatu profit dan benefit bagi keluarganya serta meminimalisir tingginya masyarakat pra sejahtera di sana, melalui metode pelatihan pembuatan suatu produk yang memiliki nilai ekonomis tinggi dengan berinovasi terhadap pada pembuatan sabun dari minyak Zaitun dengan pengemasan yang baik sehingga dapat memiliki nilai jual yang tinggi apabila dipasarkan di masyarakat. Program ini concern kepada ibu rumah tangga yang terinfeksi HIV/AIDS dengan latar belakang pada keluarga yang Pra Sejahtera dengan memberi pelatihan sampai bisa dalam membuat sebuah produk sabun dari minyak zaitun dengan inovasi baru akan memotivasi ibu rumah tangga terinfeksi HIV/AIDS untuk berwirausaha di rumahnya sehingga home industry akan menjamur di Desa Jabon. Sabun dari minyak zaitun yang akan diberikan pelatihannya kepada ibuibu di desa jabon tersebut bermacammacam warna orange, merah, pink, biru muda, putih, kuning. Bentuk bermacammacam, Aromanya beraneka macam seperti aroma buah-buahan, bunga, dsb. Dalam pelatihan ini ibu-ibu rumah tangga didesa akan mendapatkan pelatihan bagaimana cara pengemasan yang baik sehingga menarik untuk dijual pada konsumen selain sasaran penjualan pada toko atau pasar sasaran penjualan juga pada event organizer karena sabun tersebut dapat pula dijadikan souvenir ataupun parsel hantaran juga bisa untuk kesehatan pada kulit. Berikut contoh inovasi sabun dari minyak zaitun mampu meningkatkan nilai harga jual apabila 
ibu-ibu rumah tangga yang terinfeksi HIV/AIDS di desa tersebut berwirausaha mandiri setelah mendapat pelatihan:

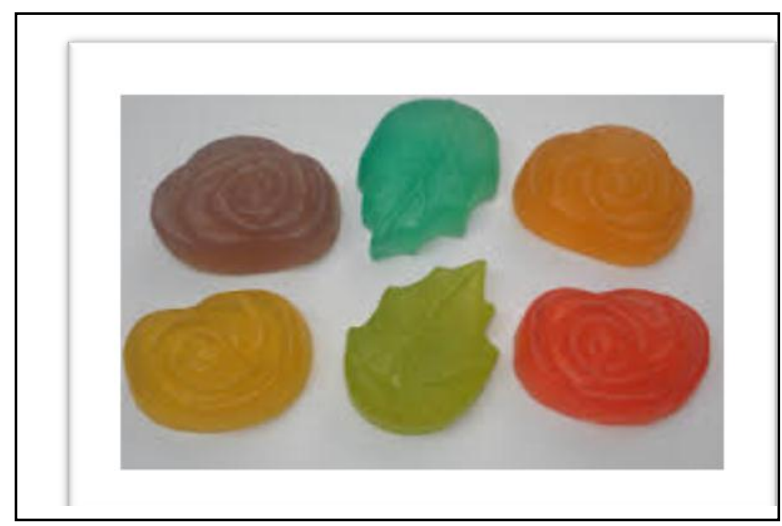

Gambar. 3 Aneka Warna Sabun Bentuk Bunga

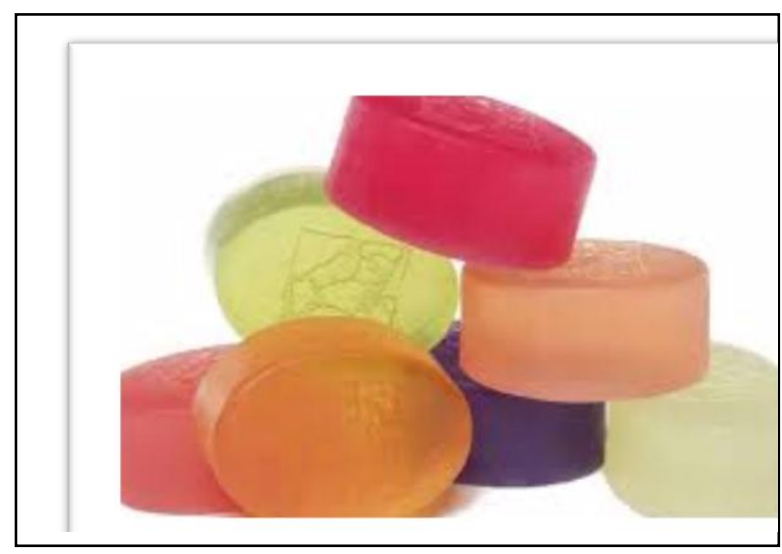

Gambar. 4 Aneka Warna Sabun bentuk Bulat

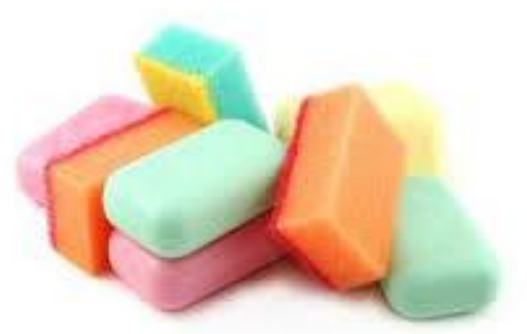

Gambar. 5 Aneka Warna Sabun bentuk segi empat

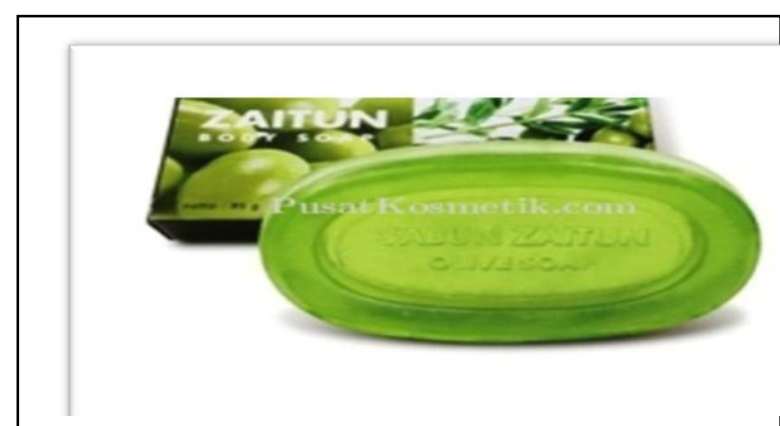

\section{Gambar. 6 Sabun Minyak Zaitun} dan Kemasannya

Target luarannyaadalah:

Jasa berupa dibukanya home industri yang bergerak di bidang sabun dari minyak zaitun

$>$ Produk berupa inovasi varian cokelat yang memiliki nilai ekonomi yang tinggi

Rencana Target Capaian:

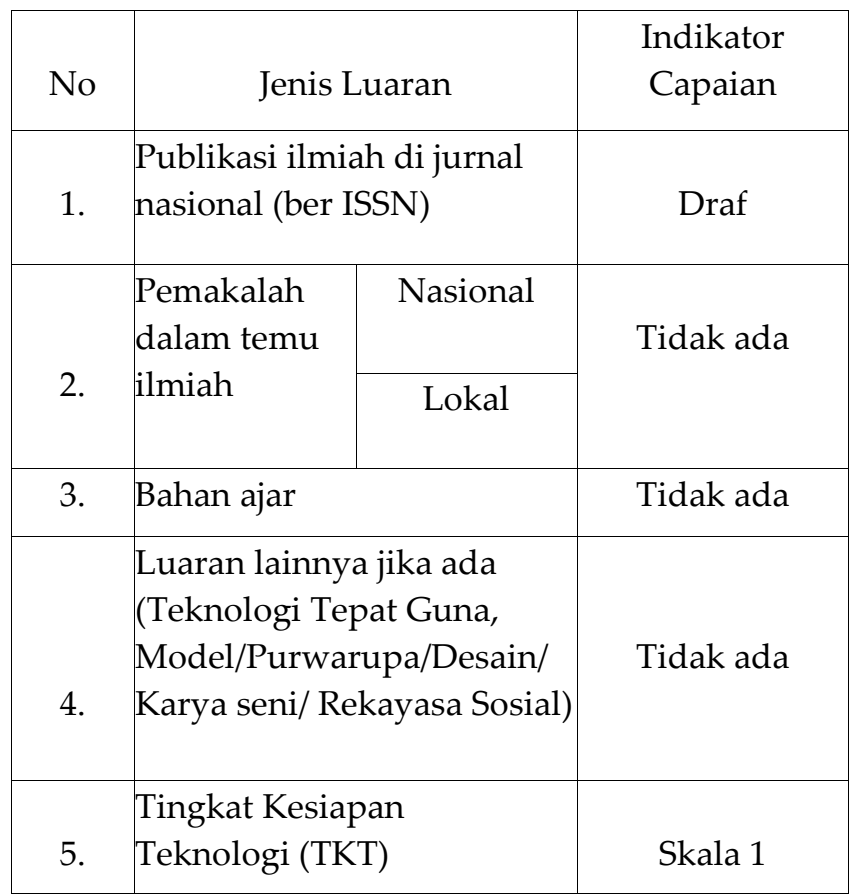




\section{METODE PELAKSANAAN}

1. Minggu ke I, Persiapan survey lokasi mitra yang sebagian besar penduduknya hanya menjadi ibu rumah tangga yang terinfeksi HIV/AIDS dan tidak memiliki usaha atau home industri secara mandiri di rumah, Meminta izin kerjasama kepada perangkat desa yang berkaitan langsung terhadap warganya terkait akan dilaksanakannya pada program pelatihan terhadap ibu-ibu rumah tangga yang terinfeksi HIV/ didaerah tersebut.

2. Minggu ke I, Menjalin kerjasama dengan cara menghubungi Mitra yang akan memberikan pelatihan cara-cara pembuatan sabun dari minyak zaitun dengan berbagai bentuk, warna, dan pengemasan.

3. Minggu ke II melakukan sosialisasi awal kepada sasaran yang akan diberdayakan untuk dilakukan pelatihan pembuatan sabun dari minyak zaitun dengan berbagai varian bentuk, warna dan pengemasan

4. Minggu ke III, Pelaksanaan pelatihan pada pembuatan sabun minyak zaitun dengan berbagai bentuk, warna dan pengemasannya. Serta pembagian bahanbahan resep pada sasaran yang diberikan pelatihan beserta resep dan cara pengemasan yang baik dan menarik sehingga memiliki nilai jual yang tinggi.

5. Minggu ke IV, Pelaporan hasil pada Praktek Kemitraan Masyarakat dan pelaporan anggaran pengeluaran program kemitraan masyarakat.

\section{HASIL DAN PEMBAHASAN}

Pelaksannaan Kegiatan Pelatihan pada Pembuatan sabun dari minyak zaitun dengan varian inovasi bentuk, warna dan Pengemasannya kepada Ibu Rumah Tangga yang terinfeksi HIV /AIDS di Desa Jabon Kecamatan Jombang Kabupaten Jombang. Kegiatan pelatihan dilakukan kepada Ibu rumah tangga terinfeksi HIV/AIDS di Desa Jabon dengan beberapa kegiatan dan langkah sebagai berikut :

1. Pengabdi mendatangkan narasumber untuk melakukan pelatihan pada Ibu rumah tangga yang terinfeksi HIV/AIDS dan latar belakang masyarakat Pra sejahtera di desa Jabon, Kabupaten Jombang.

2. Pengabdi mempersiapkan bahanbahan yang digunakan selama pelatihan berlangsung diantaranya bahan yang diperlukan yaitu : minyak zaitun, minyak sawit, minyak kelapa, $\mathrm{NaOH}$, dll. 
3. Selanjutnya tahapan-tahapan pembuatan sabun dibagikan oleh pengabdi kepada Ibu rumah tangga terinfeksi HIV/AIDS yang berlatar belakang masyarakat pra sejahtera di Desa Jabon berbentuk Resep yang dibagikan kepada Mitra, berikut resep dari sabun dari minyak zaitun dengan variasi dan inovasi isi:

\section{Bahan-bahan yang dibutuhkan :}

\section{Bahan:}

1. 50 gram : Minyak zaitun

2. 340 gram minyak sawit

3. 170 gram minyak kelapa

4. 109 gram $\mathrm{NaOH} / \mathrm{KOH}$

5. 250 gram Air

6. $60 \mathrm{cc}$ Palm oil

7. $10 \mathrm{cc}$ fragrance Pewarna secukupnya

8. Zat Aditif : Rempah, herbal, talk, tepung, kanji atau maizena secukupnya

\section{Alat-Alat yang dibutuhkan:}

1. Masker sederhana dipakai selama pembuatan larutan $\mathrm{NaOH}$ / KOH saja.

2. Kacamata dipakai selama pembuatan larutan $\mathrm{NaOH} / \mathrm{KOH}$ saja.

3. Sepasang sarung tangan karet dipakai selama pembuatan sabun.

4. Botol Plastik untuk wadah air.

5. Timbangan dapur (dengan skala terkecil 1 atau 5 gram).
6. Kantong plastik kecil untuk menimbang $\mathrm{NaOH} / \mathrm{KOH}$.

7. Sendok stainless steel atau plastik polipropilen untuk menuangkan $\mathrm{NaOH} / \mathrm{KOH}$ dan mengaduknya.

8. Wadah dari gelas atau plastik polipropilen untuk tempat larutan $\mathrm{NaOH} / \mathrm{KOH}$ dengan air.

9. Wadah dari plastik untuk menimbang serta tempat air dan minyak.

10. Kain untuk menutup cetakan setelah diisi sabun.

11. Plastik tipis untuk melapisi cetakan.

12. Cetakan

13. Blender dengan tutupnya.

\section{Cara Pembuatan :}

1. Timbang air dan $\mathrm{NaOH} / \mathrm{KOH}$, sesuai dengan Resep. Larutkan $\mathrm{NaOH}$ / $\mathrm{KOH}$ ke dalam air sejuk / dingin (Jangan menggunakan wadah aluminium. Gunakan stainless steel, gelas pyrex atau plastik-poliproplen). Jangan menuangkan air ke $\mathrm{NaOH} /$ $\mathrm{KOH}$. Tuangkan $\mathrm{NaOH} / \mathrm{KOH}$ ke dalam air sedikit demi sedikit. Aduk higga larut. Pertama-tama larutan akan panas dan berwarna keputihan. Setelah larut semuanya, simpan di tempat aman untuk didinginkan 
sampai suhu ruangan. Akan

didapatkan larutan yang jernih.

2. Timbang minyak (Minyak Kelapa, Minyak Sawit, Minyak Zaitun, Minyak Jagung, Minyakkelapa) sesuai dengan Resep.

3. Tuangkan minyak yang sudah ditimbang ke dalam blender.

4. Hati hati tuangkan larutan $\mathrm{NaOH} /$ $\mathrm{KOH}$ ke dalam minyak.

5. Pasang cover blender, taruh kain di atas cover tadi untuk menghindari cipratan dan proses pada putaran terendah. Hindari jangan sampai menciprat ke muka atau badan anda. Hentikan blender dan periksa sabun untuk melihat tahap "trace". "Trace" adalah kondisi dimana sabun sudah terbentuk dan merupakan akhir dari proses pengadukan. Tandanya adalah ketika campuran sabun mulai mengental. Apabila disentuh dengan sendok, maka beberapa detik bekas sendok tadi masih membekas, itulah mengapa dinamakan "trace".

6. Pada saat "trace" tadi anda bisa menambahkan pengharum, pewarna atau aditif. Aduk beberapa detik kemudian hentikan putaran blender.

7. Tuang hasil sabun ini ke dalam cetakan. Tutup dengan kain untuk insulasi. Simpan sabun dalam cetakan tadi selama satu hingga dua hari. Kemudian keluarkan dari cetakan, potong sesuai selera. Simpan sekurang-kurangnya 3 minggu sebelum dipakai.

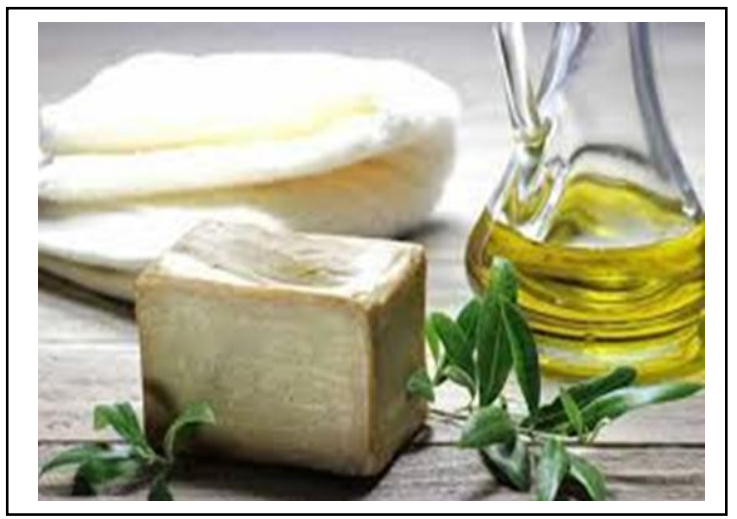

Gambar 7 Sabun dari Minyak Zaitun

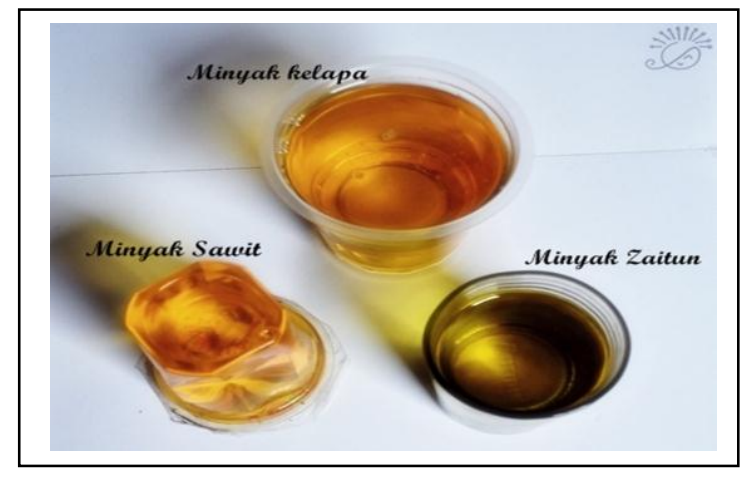

Gambar. 8 Minyak Zaitun, Sawit Dan Kelapa 


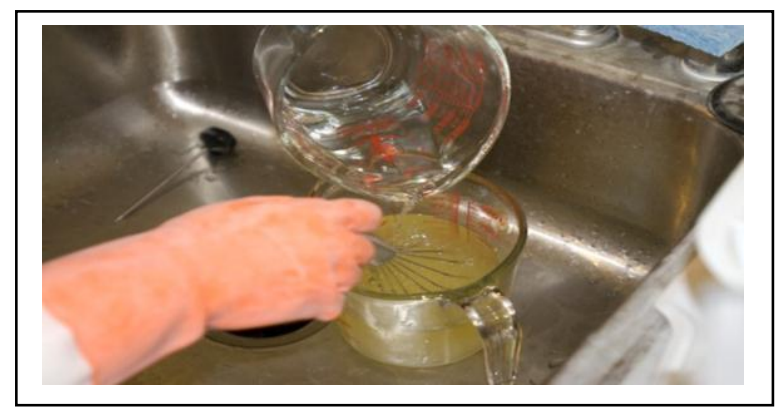

Gambar. 9 Menuangkan Minyak Zaitun

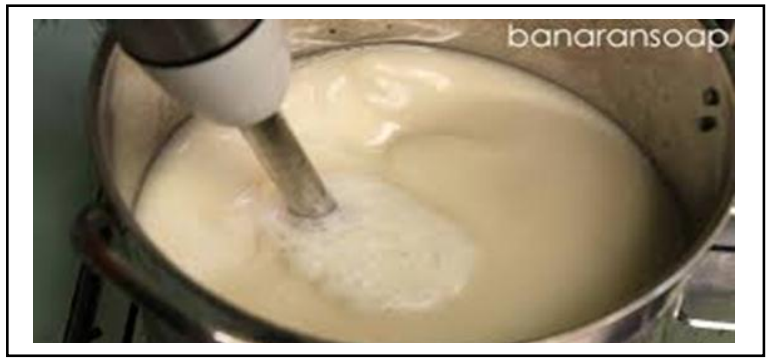

Gambar . 10 Blender Sabun Minyak Sabun Zaitun

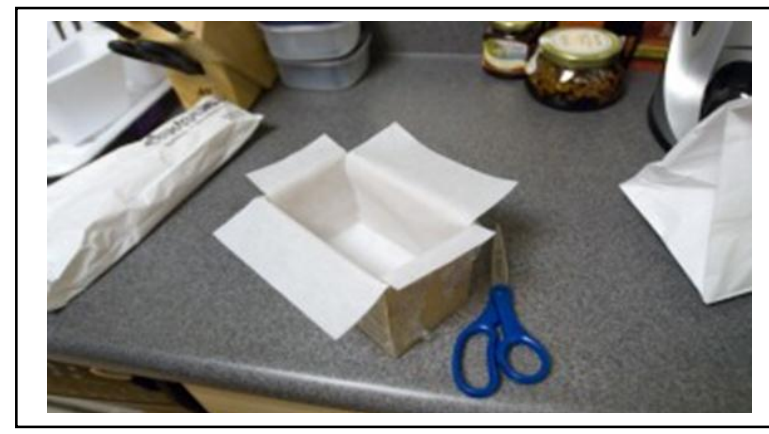

Gambar. 11 Buat Tempat Sabun /Cetak

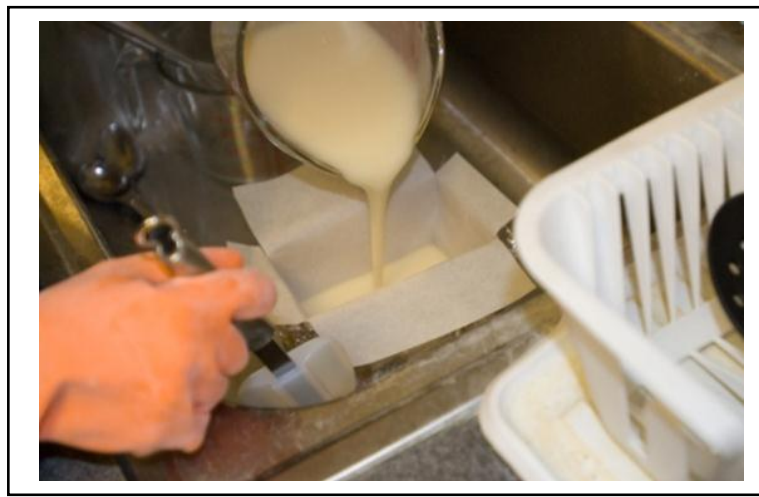

Gambar 12 Memasukan Ke Cetak Sabun

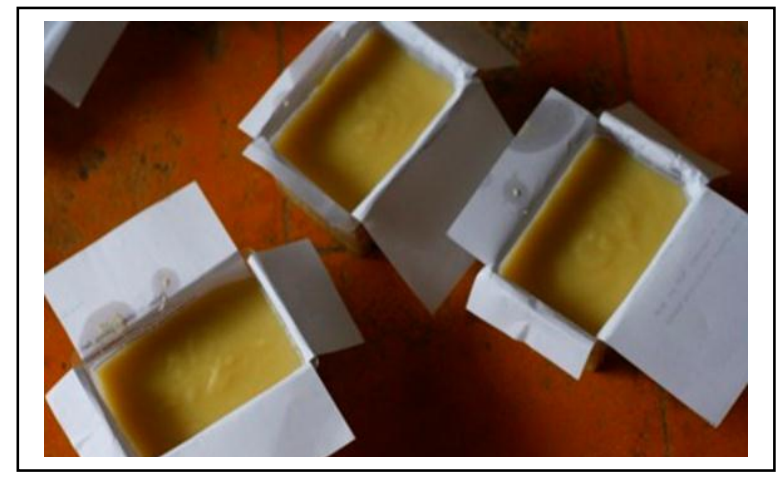

Gambar 13 Sabun di Cetak

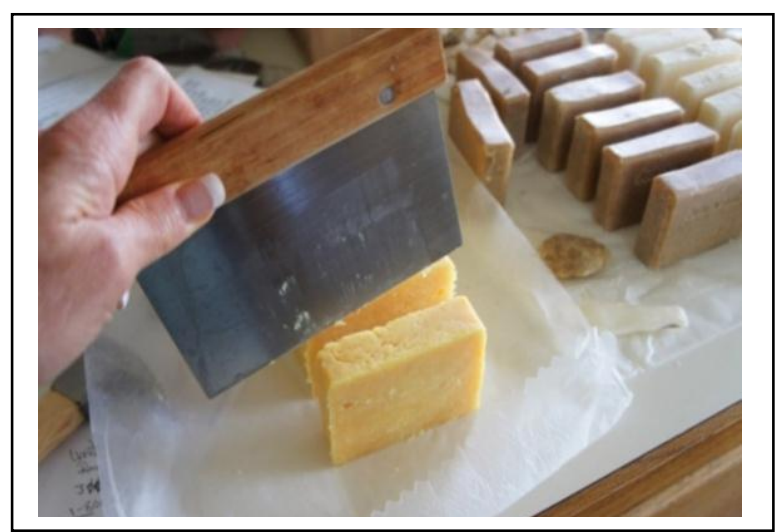

Gambar. 14 Sabun Zaitun di potongpotong

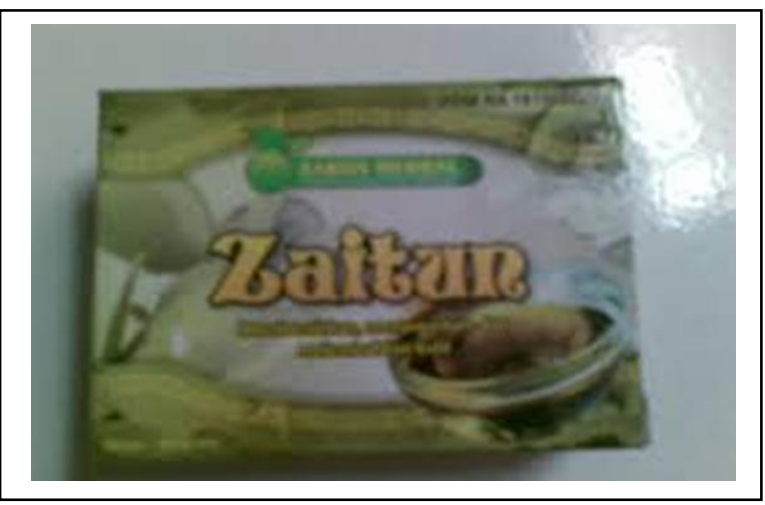

Gambar. 15 Contoh Kemasan Sabun

\section{SIMPULAN DAN SARAN}

\section{Kesimpulan}

Berdasarkan hasil kegiatan yang sudah dilakukan di lokasi kegiaatn 
maka dapat disimpulkan beberapa hal sebagai berikut :

1. Selama ini para Ibu rumah tangga yang terinfeksi HIV/AIDS berlatar belakang masyarakat pra sejahterah yang mengandalkan biaya dari kepala keluarga tanpa memiliki kemauan untuk berwirausaha dengan alasan tidak memiliki dana yang lebih untuk bisat membuka usaha.

2. Belum adanya pelatihan pelatihan untuk dapat mendobrak kewirausahaan mandiri kepada ibu- ibu rumah tangga (ODHA) di sana, program hanyalah dari PKK dan pengajian saja namun tidak mencakup upayapelatihan kewirausahaan mandiri.

3. Antusias ibu-ibu rumah tangga yang berlatar belakang masyarakat pra sejahtera terhadap pelatihan, dan bingkisan sumbangan yang telah diberikan untuk dimanfaatkan kedepannya.

\section{Saran :}

1. Diperlukan koordinasi yang baik antara pengurus PKK, RW dan RT setempat terhadap warganya khususnya Ibu rumah tangga yang terinfeksi HIV/AIDS berlatar belakang masyarakat Pra Sejahtera untuk mendongkrak peran serta mereka berwirausaha mandiri sehingga tingkat kesejahteraan masing-masing keluarga di Desa Jabon Jombang dapat meningkat secara bertahap.

2. Diperlukan pendampingan pelatihan secara berkelanjutan guna monitoring dan evaluasi terhadap program kemitraan masyarakat yang sudah dilaksanakan, sehingga tidak hanya menjadi pelatihan satu kali saja namun berkesinambungan.

3. Mengembangkan kewirausahaan mandiri pada ibu rumah tangga yang terinfeksi HIV dan AIDS, ibu rumah tangga yang berlatar belakang Pra Sejahtera dan ibu rumah tangga di Desa Jabon Kabupaten Jombang.

\section{REFERENSI}

Badan Pemberdayaan Masyarakat Kab. Jombang, 2017. Buku Panduan Profil Desa dan Kelurahan Jobon Kabupaten Jombang.

Badan Pemberdayaan Masyarakat Kab. Jombang, 2017. Daftar Isian Data Dasar Profil Desa/keluraha Jabon, Kecamatan Jombang, Kabupaten Jombang.

Dinas Kesehatan. 2018. hasil kegiatan tahun 2016 dan rencana kerja tahun 2016. Bidang Pencegahan dan Pemberantasan Penyakit HIV/AIDS. Jombang.

Kelurahan Jabon Jombang, 2018. Data di 
Kabupaten Jombang.

WHO. Human Immunodeficiency Virus HIV/AIDS: WHO, 2016. [cited 2016 Nov

8].Available.from:http:// www.who.int/ features/qa/71/en/.

ZainulArifin,http://www.visioner.id/opi ni/9933/program-pemberdayaanmasyarakat pada upaya-meningkatkankesejahteraan-dalam masyarakat-desa-2. html, diakses tanggal 20 Juli 2018 